\title{
Особливості використання новітніх інформаційних технологій в психологічному консультуванні
}

\begin{abstract}
Анотація. В статті розглянуті актуальні проблеми надання психологічної допомоги оп-line в реальному часі. Розкриваються перспективні засоби надання психологічної допомоги дистанційно для людей з обмеженими можливостями, для тих, хто живе далеко від міста, та тих, хто хоче зберегти максимальну анонімність консультації. Досліджено, як психологічна допомога може надаватися різними засобами, наприклад: Skyре, текстові повідомлення, форуми, вебінари та іншими мультимедійними засобами. Після опрацювання результатів були зроблені висновки, щзо основною вимогою до психолога виявилась наявність інформаційної компетентності, самопрезентації, щзо включає в себе його аватарку, зовнішній вигляд, правильну вимову, щвидкість реакиії. Отже, сьогодення ставить перед психологом-консультантом такі нові вимоги, як вимога до самопрезентації, тобто якщчо психолог консультує через Skyре, то він має розуміти важливість свого зовнішнього вигляду, повинен відповідати тому образу, якого вимагає професія, та мати охайний вигляд, якщзо психолог консультує на чатах, форумах та в соимережах, його аватарка повинна відповідати професійному змісту, бажано, щзоб ие була фотографія самого консультанта, щзо відображає його професійну постать. Вимога до володіння інформаційною компетентністю, коли психолог-консультант розуміє, щзо за недосконалого володіння технічними засобами існує можливість переривання онлайн-консультації, $і$ клієнт може ніколи не зважитись на подібне спілкування онлайн. Вимога до писемної грамотності психолога: за консультування у чатах, форумах та сочмережах, допущення психологом помилки, опечатки може слугувати приводом для клієнта перервати консультацію.

Ключові слова: інтернет-консультація, психологічна допомога, реальний час, інформаційна компетентність, самопрезентація, аватар, онлайн-консультація, інформаційні технології.
\end{abstract}

Постановка проблеми. Стрімкі зміни, що відбуваються зараз у суспільному житті, породжують велику кількість життєвих проблем особистості. Це, у свою чергу, обумовило виникнення потреби у психологічному забезпеченні соціальних процесів. Актуальними залишаються проблеми сімейних та подружніх стосунків, виховання дітей. У зв'язку з цим значення психологічного консультування в Україні посилюється. Все більше стає людей, що звертаються до психологів з різними проблемами, такими, як соціальні проблеми, робота або iї відсутність, проблеми сім'ї та шлюбу, невпевненість у собі, нездатність приймати рішення тощо, що призводить до тих чи інших варіантів дезадаптації особистості.

Мета статті дослідити новітні інформаційні технології надання психологічної допомоги on-line в реальному часі.

Психологічна практика здійснюється або безпосередньо шляхом міжособистісного спілкування, або опосередковано че- рез предметну або змістовну діяльність. Метою будь-якої психологічної практики $є$ зміни стану або зміни свідомості суб'єкта (ставлень, переконань, уявлень, емоцій та ін.), рис або якостей особистості, зміни поведінки [3].

В той же час існує категорія людей, для яких психологічна допомога практично недоступна, через нездатність самостійно рухатись (інваліди), проживання у сільській місцевості, ізоляцію (особи що позбавлені волі) або тому, що вони прив'язані до дому внаслідок хвороби або старості. Крім того, існують категорії людей, що перебувають у кризовому стані, які не готові піти на консультацію в силу специфіки їх характеру або хвороби (ВІЧ-інфіковані або наркомани), страху порушення конфіденційності (сексуальні розлади, сімейне насильство). Тому в усьому світі швидко розвиваються види дистантної психологічної допомоги через різні засоби на основі текстової комунікації, які називаються 
психотерапією онлайн, інтернет консультуванням, кібертерапією.

Інструменти для проведення психологічних консультацій обираються найбільш зручні з існуючих:

1. Консультації телефоном (за допомогою додатків у мобільних смартфонах, коли абонент відправляє SMS iз запитом до психологічної служби).

2. Консультації через E-mail.

3. Консультації через Skype.

Переваги онлайн-консультування для клієнта:

1. Ніхто не дізнається персональних даних клієнта, гарантується повна анонімність.

2. Вартість онлайн консультації нижча, ніж у психолога, який приймає особисто.

3. Консультуватись можна з будь-якого місця, де $\epsilon$ комп'ютер або телефон. Де б не був клієнт, де б не був консультант зв'язок між ними не рветься, а консультації можна проводити без вимушених перерв. Клієнт обирає найбільш зручний час для проведення консультації.

4. Важливим аспектом у консультуванні $\epsilon$ документування отриманої інформації. За час консультації клієнт одержує значний обсяг нової інформації, яку не завжди можна засвоїти одразу. При спілкуванні онлайн можна перечитувати історію консультацій скільки завгодно, освіжаючи в пам'яті і відкриваючи для себе нові межі власного світогляду.

Інтернет-консультування — це альтернативне джерело психологічної допомоги в тих випадках, коли традиційне психологічне консультування недоступне або неможливе. Для деяких людей це єдиний спосіб отримати консультацію психолога. Інтернет-консультування — не заміна традиційного психологічного консультування. Інтернет-консультування підходить Вам, якщо:

- Ви не можете відвідувати очні консультації через хворобу, панічні атаки тощо;

- Ви проживаєте або тимчасово перебуваєте за кордоном і вважаєте за краще консультуватися у вітчизняного психолога;
- Вам зручніше отримати консультацію в письмовому вигляді і не виходячи 3 дому через занадто високу зайнятість або з інших причин;

- Вам важко прийти на очне консультування (сором, неординарність проблеми, неоднозначність або прагнення підвищити рівень конфіденційності);

- у Вашому місті немає психологічних консультаційних центрів або приватно практикуючих психологів.

Як відбувається Інтернет-консультування? Більшість Інтернет-консультантів працює за допомогою:

- ICQ;

- Відео-конференції;

- Інтернет-телефону.

Тим не менш, можна виділити окремі специфічні особливості Інтернет-консультування:

По-перше, процес Інтернет-консультування має двосторонню змістову специфіку щодо критерію анонімності, тобто публічності особистості клієнта. 3 одного боку, процес консультування для клієнта анонімний, що обумовлено тим, що в Інтернеті (в чаті, «де», як правило, і здійснюється Інтернет-консультування) клієнт (у більшості випадків) виступає під вигаданим ім'ям. При цьому, навіть якщо клієнт буде відомий під своїм справжнім ім'ям, все одно, йому практично гарантована анонімність, оскільки людей $з$ однаковими іменами в країні сотні тисяч. 3 другого боку, процес Інтернет-консультування для клієнта публічний, оскільки таке консультування відбувається, як правило, в чатах або на форумах, «де» всі питання клієнта і відповіді консультанта доступні загалу. Таким чином, забезпечується публічність процесу Інтернетконсультування, тому що всі хто «сидить в чаті» або «перебуває на форумі», бачать на екранах своїх моніторів процес Інтернет-консультування, спостерігають порядок та послідовність питань і відповідей та оцінюють їх зміст.

По-друге, змістовою особливістю Інтернет-консультування $\epsilon$ його інтерактив- 
ний характер. У процесі Інтернет-консультування його учасники (в першу чергу клієнти, але іноді і консультанти) можуть втручатися у процес консультування психологом конкретного клієнта, даючи свої коментарі до того, що відбувається, оцінюючи смислове підгрунтя обговорюваних тем. Причому це може відбуватися як у довільному (свобода самовираження), так і в заданому порядку, — коли вже відомі один одному учасники (при груповому варіанті Інтеренет-консультування) обговорюють за допомогою психолога-консультанта спільні для них усіх проблеми.

По-третє, змістовою особливістю $\mathrm{IH}_{-}$ тернет-консультування $\epsilon$ його доступність, куди ми включаємо, перш за все, психологічну зручність і фізичний комфорт (клієнт сидить вдома за своїм персональним компьютером) для користувача Інтернетконсультування. Тут яскраво проявляється можливість для клієнта функціонально швидко (легкість прийняття рішення) «увійти в чат» - що не спричинює необхідності участі в обговоренні, оскільки іншим учасникам процесу Інтернет-консультування невідомо, хто саме «перебуває у чаті» (максимально відома інформація це кількість осіб в режимі онлайн присутніх у чаті чи форумі). Все це призводить до того, що у будь-якого учасника задовольняється потреба в психологічній безпеці, що, безумовно, дуже важиво в процесі будь-якої особистісної комунікації.

По-четверте, смислову специфіку Інтернет-консультування складає його навчальний характер, тому що безліч людей може одночасно брати участь у даному процесі як просто спостерігаючи його, так і висловлюючись, коментуючи і навчаючись на «помилках» інших, — тоді, коли обговорюються цікаві для конкретної людини проблеми. Таким чином, сама участь людини в процесі Інтернет-консультування, iіi «присутність» (лапки умовні, тому що в цьому процесі $є$ дві базові сторони спілкування, що розуміється як діяльність (А. В. Леонтьєв, А. В. Петровський, А.І. Донцов) [1], - комунікація і інтеракція) на консультативному Інтернетфорумі або в консультативному Інтернет- чаті, має навчальний ефект в силу того, що інформативність такого роду взаємодії для окремо взятої людини порівняна 3 продуктивністю участі іiї у процесі класичного групового консультування.

Нарешті, по-п’яте існує, на нашу думку, ще одна смислова змістова особливість Інтернет-консультування, що розглядається нами як нова технологія психологічного консультування. Мається на увазі професійна діяльність психолога-консультанта. Вважаємо можливим сутнісно (за основними властивостями) порівняти іiі з діяльністю консультанта, який здійснює групове психологічне консультування, і виокремити основні подібності та відмінності цих двох професійно-діяльнісних парадигм. Як нам видається, основна зовнішня схожість цих двох консультативних парадигм у їх колективності, масовості, яка, тим не менш, безумовно в рази вища в Інтернет-консультуванні. Також ми вважаємо, що основною внутрішньою відмінністю Інтернет-консультування від класичного групового консультування $є$ різний якісний характер третьої базової сторони спілкування як взаємодії - соціальної перцепції, професійно здійснюваної психологом-консультантом. Якщо в процесі класичного індивідуального i, багато в чому, класичного групового консультування психолог зобов'язаний у повній мірі «...слухати, емпатіювати і чекати», — як писав Ірвін Ялом [7], то в процесі Інтернет-консультування для психологаконсультанта зовсім не обов'язкого настільки глибоко особистісно емоційно зовні реагувати на особистісні прояви клієнтів. У процесі Інтернет-консультування психологу досить мати розвинену когнітивну особистісно-професійну складову для того щоб бути успішним консультантом [8]. Це істотно полегшує для нього сам процес Інтернет-консультування - знижує його емоційні витрати і дозволяє концентруватися на проблемі, а не на людині. Щоправда знижує і продуктивність Інтернет-консультування, тому що відсутність емоційно-чуттєвої складової в соціальній перцепції, як доведено, наприклад, Ірвіном Яломом, дуже негативно позначається 
на психотерапевтичному ефекті консультативної взаємодії [8].

Існує кілька моделей, способів надання психологічної допомоги в Інтернеті. Ці способи визначаються залежно від потреб клієнта. Найчастіше пропонуються індивідуальне консультування або участь у форумі, який підбирається залежно від вікової категорії клієнта та його особистісних переваг. Онлайн консультанти можуть допомогти людині розібратися в собі, працюють 3 неважкими психологічними травмами клієнтів, допомагають їм вирішувати конфліктні ситуації в житті тощо.

Розглянемо змістові процесуальні особливості психологічного Інтернет-консультування.

Об'єктивна «слабкість» психологічного консультування в Інтернеті полягає в неможливості психолога реально протестувати клієнта, побачити його стан, манери поведінки, «прочитати» міміку і жести. Іншими словами, психолог не може отримати достовірну невербальну діагностичну інформацію про свого клієнта.

Оскільки, у більшості випадків, психологічна консультація в мережі Інтернет проводиться за принципом питання-відповідь, то клієнт не надає достатнього обсягу інформації про себе і свою проблему. Через що відповіді можуть бути узагальненими та поверховими. Серйозним «козирем» для психолога Інтернет-консультанта $\epsilon$ в цьому випадку професійна інтуїція.

Як не дивно, деякі люди навіть в мережі можуть соромитися своїх психологічних проблем. Це, як правило, спричинене тим, що людина не наважується сама собі зізнатися в особистісних причинах власних проблем. Подібні фактори можуть спонукати клієнта нещиро викладати свої проблеми і вести різні психологічні ігри з консультантом. Під психологічними іграми, в даному смисловому контексті, мається на увазі нещире звернення клієнта до психолога 3 метою отримати від нього компетентну допомогу, нічим при цьому не жертвуючи, нічого в собі не змінюючи і не приймаючи відповідальності за свої проблеми [4].
Незважаючи на подібний недолік психологічного консультування в Інтернеті, у нього як у нової технології психологічного консультування $є$ і свої переваги. До них належить, зокрема, так званий «ефект супутника», що має певну соціально-психологічну основу [2]. Ефект супутника полягає в тому, що одна людина може абсолютно щиро «виговоритися» іншій людині, знаючи, що вона більше ніколи пї не побачить. Якщо б ці люди жили поруч в одній місцевості, то такого б не сталося. Це уявлення людей «про сповідь» прийшло зі спільних поїздок у рейсових автобусах далекого сполучення, поїздок в поїздах, польотів у літаках тощо, коли люди, зустрівшись одного разу, після цього ніколи більше не побачаться. В інформаційному Інтернет-середовищі може відбуватися практично те ж саме з тією лише різницею, що людина може «заховати» свою персону за вигадане ім'я i, відчуваючи свою повну психологічну безпеку, повністю «розкрити свою душу». Подібна щирість клієнта, в основному саме перед самим собою, вже містить цілющий психотерапевтичний ефект і може вести до вирішення психологічної проблеми [4]. Також і сам процес опису клієнтом особистої проблеми, автобіографіï, характеру своїх переживань, феноменології власної особистості - відноситься до продуктивних психологічних технік, оскільки дозволяє людині більш широко i чесно поглянути на себе [6].

Те ж саме стосується й «виливання себе на папері». Подібна «письменницька праця», тотожна творчому самовираженню, $\epsilon$ цілющим психологічним засобом, що призводить до усвідомлення себе і своєї проблеми в ширшому контексті, а також до «отримання» раптових розв'язків, відкриттів і одкровень. Часом навіть систематизований опис власної життєвої проблеми може приводити до полегшення душевного стану [3]. Цей ефект в соціально-психологічному плані, звичайно ж, у багато разів посилюється в умовах психологічного консультування, яке сьогодні технологічно здійснюється звичайною поштою, елект- 
ронною поштою, sms, mms, у чатах, на форумах і т.п.

Досвідчений психолог-консультант, в тому числі й Інтернет-консультант, може швидко встановити достовірність «розповіді» клієнта про свою проблему і своє життя, вивчивши його писання, - що може відбуватися як в режимі on-line, так і в режимі off-line, тобто в реальному часі або «покроково». При цьому навідні запитання психолога-консультанта повинні потрапляти «в точку», викликаючи вивільнення у клієнта пригнічених емоцій i усвідомлення ним власних комплексів та самообмежень.

Ефект Інтернет-форумів 3 психологічним змістом часто тотожний груповій психотерапії, особливо якщо люди вчаться висловлювати не тільки свої думки, але й свої почуття. Швидше за все, Інтернет-консультування, що розглядається нами як нова технологія психологічного консультування, буде у майбутньому швидко розвиватися. Для цього ми маємо, як мінімум, два важливі чинники. Перший чинник полягає у постійному розвитку i дедалі більшій доступності Інтернету. Другим чинником $\epsilon$ помітна на сьогоднішній день у молодіжному середовищі соціально-психологічна тенденція, що виражається в прагненні молодих людей саме до віртуального спілкування [3].

Чим же може все-таки позначити себе ефективний психолог в Інтернеті? Мабуть, йому необхідна особиста Інтернет-сторінка (web-сайт), а краще форум, у якому він міг би демонструвати свої судження i приклади консультування. Початківець Інтернет-консультант, в будь-якому випадку, повинен спочатку консультувати безкоштовно, оскільки на невідомого в мережі Інтернет-консультанта навряд чи зреагують Інтернет-користувачі.

Інтернет-консультування $є$ дистанційною формою психологічної допомоги. Звернення до Інтернет-психолога - це ефективний і безпечний спосіб виходу з кризи та вирішення проблем. Для тих, хто бажає вирішити свої проблеми 3 мінімальними витратами часу, здоров'я, грошей і сил, сьогодні пропонується саме Інтернет-консультування. У процедурі Інтернет-консультування клієнт може вирішувати свої особистісні проблеми ефективно й у своєму власному темпі і ритмі. Тоді, коли людина звертається до Інтернет-психолога, вона «входить»у особливий психологічний простір — безпечне поле, що сприяє збільшенню іï внутрішнього особистісного потенціалу, його саморозкриття. Адже саме в цих умовах людина знаходить вихід зі складних життєвих обставин, приймає потрібне рішення, розуміє й усвідомлює свої емоції, знаходить внутрішній спокій і віру у власні сили.

Існує думка, що психологічна допомога може бути тільки очною. Звичайно, у очної форми психологічної допомоги є свої незаперечні переваги. Дійсно, стандартна процедура допомоги будується на очній основі. Це, втім, в основному стосується тих варіацій очного психологічного консультування, коли психолог і клієнт зустрічаються досить довго. Саме тоді, як правило, і «спрацьовують» всі відомі позитивні ефекти професійного безпосереднього спілкування. Класичне психологічне консультування засноване саме на тих «технічних прийомах», які передбачають безпосереднє спілкування. I все ж, якщо розглядати психологічну допомогу більш широко, ми знайдемо всілякі форми іï реалізації: від консультування телефоном до читання рекомендованої кимось або обраної за своїм бажанням літератури [3].

Протягом 2013 року ми здійснили емпіричне дослідження, у якому брали участь студенти Києво-Могилянської академії. Процентне співвідношення статей респондентів було практично однаковим. Віковий діапазон респондентів варіювався від 18 до 22 років. Одним із завдань дослідження було виявити особливості оцінки студентами наданої психологічної допомоги різними технічними засобами - консультування, що представляло собою обмін меседжами на форумах та чатах, та використання Skype. Для оцінки ефективності нашої діяльності, після консультації респонденту було запропоновано питальник. 
Питальник:

1. Скільки Вам років?

2. Чи зверталися Ви в минулому до психолога або психотерапевта?

3. Ви користуєтесь Інтернетом дома?

4. Чи маєте Ви у своєму телефоні дадаток Skype та соціальні мережі?

5. Чи можна сказати, що на момент звернення до нас Вам було дійсно погано?

6. На що Ви очікували, звертаючись по допомогу?

7. Чи мали Ви раніше досвід консультування через Skype?

8. Чи мали Ви раніше досвід консультавання через форуми, чати, соціальні мережі?

9. Яке з видів консультування Ви обрали: очне чи заочне?

10. Які особливості консультування через Skype Ви виокремили?

11. Які особливості консультування через форуми, чати, соціальні мережі Ви виокремили?

12. Порекомендували б Ви нас своїм друзям за умови надання їм можливості користування Інтернетом?

13. Що б Ви могли конкретно нам побажати і порекомендувати в нашій подальшій діяльності?

Після опрацювання матеріалу були отримані наступні результати:

- Консультуванню через Skype та вебінари надали перевагу $52 \%$ респондентів, вони виділили такі особливості психолога-консультанта, як: самопрезентація психолога, що включає в себе його аватарку, зовнішній вигляд, правильну вимову, швидкість реакції; володіння технікою роботи 3 мікрофоном, навушниками тощо.

- Косультації на форумах, чатах, у соціальних мережах віддало перевагу $48 \%$ - менша частина респондентів; виділені такі особливості психологаконсультаната, як: самопрезентація психолога, що включає в себе його аватарку, нікнейм, писемну грамотність, швидкість реакції; психологконсультат повинен бути зареєстро- ваний у форумах, чатах, соціальних мережах, через які він надає психологічну допомогу.

Висновки. Інтернет-консультуванням як формою психологічної допомоги може скористатися практично будь-яка людина; на сучасному етапі в Україні майже в усіх віддалених від обласних центрів селах в школах $є$ Інтернет. Однак $є$ кілька умов, які визначатимуть ефективність подібної дистанційної психологічної допомоги. Ефективність, продуктивність ця пов'язана, перш за все, із самим суб'єктом, який звертається по допомогу. Наскільки людина готова скористатися нею, наскільки людина готова щось змінювати в собі, наскільки актуальна іiі проблема, наскільки в людині розвинена здатність спостерігати саму себе, наскільки людина мотивована на пізнання себе і т.п.

Психологічне Інтернет-консультування дозволяє здійснювати інтеграцію фахівців різних напрямків психології на одному консультаційному сайті з метою надання швидкої кваліфікованої психологічної допомоги широкому спектру клієнтів. Система психологічного онлайн Інтернет-консультування дозволяє брати участь у консультаційних Інтернет-проектах великій кількості фахівців, навіть 3 різних міст, що працюють у руслі різних психологічних шкіл і течій. Клієнти мають можливість обрати того професіонала, який їм ближчий за стилем роботи. Система Інтернет-консультування відкрита і доступна кожному — як фахівцям, так і клієнтам. Одночасно на одному професійному сайті можуть консультуватися кілька десятків людей. Система онлайн Інтернет-консультування, загалом і в цілому, є групою технологічних програм і проектів, що дозволяють організувати закриті, індивідуальні консультації в рамках стосунків клієнт-фахівець.

Одне $з$ головних переваг Інтернету це можливість для людей спілкуватися між собою на відстані, за бажання - 3 повною анонімністю. Причому завдяки можливостям Інтернету це спілкування може проходити в режимі реального часу. 
У нашій країні культура звертання за очними консультаціями до психолога недостатньо сформована. Тоді на допомогу приходить психологічне Інтернет-консультування. Людина може отримати консультації психолога анонімно: ніхто не буде знати ї̈ призвища, імені, по батькові, вона може придумати собі псевдонім, приховати або змінити свою стать, вік, професію тощо. Основним із перспективних напрямків дослідження є дослідження інформаційної компетентності психолога-консультанта.

\section{Список використаних джерел:}

1. Донцов А. И. Психология коллектива / А. И. Донцов. - М. : МГУ, 1984. - 207 с.

2. Донцов А. И. Проблемы групповой сплоченности / А. И. Донцов. - М. : МГУ, 1979. $128 \mathrm{c}$.

3. Збірник Всеукраїнської науково-практичної конференції «Актульні проблеми практичної психології» (29 березня 2012 року м. Київ) / Національний педагогічний університет імені М.П. Драгоманова. - К., 2012. - 361 с.

4. Кочюнас Р. А. Основы психологического консультирования / Р. А. Кочюнас; [пер. с лит.]. - М. : Академический проект, 1990. — 240 с.

5. Рубцов В. В. Виртуальная психологическая служба // В. В. Рубцов, С. В. Лебедева // Психологическая наука и образование. - 2002. - № 1. - С. 87-98.

6. Элизаров О.М. Концепции и методы психологической помощи: Альфред Адлер, Карен Хорни, Карл Густав Юнг, Роберто Ассаджиоли : учебное пособие / О.М. Элизаров. М. : «Ось-89», 2004. - 160 с.

7. Ялом И. Дар психотерапии / Ирвин Ялом; [пер. с англ. Ф. Прокофьева] - М. : Эксмо, 2005. - $352 \mathrm{c}$.

8. Ялом И. Лжец на кушетке / Ирвин Ялом; [пер. с англ. М. Будиной]. — М. : Эксмо, 2005. $-352 \mathrm{c}$.

Аннотация. В статье рассмортрены актуальные проблемы оказания психологической помощи онлайн в реальном времени. Раскрываются перспективные средства оказания психологической помощи дистанционно для людей с ограниченными возможностями, для тех, кто живет далеко от города, и тех, кто хочет сохранить максимальную анонимность консультачии. Исследовано, как психологическая помощь может представляться различными способами, например: скайп, текстовые сообщения, форумы, вебинары и другими мультимедийными средствами. После обработки результатов были сделаны выводы, что основным требованием к психологам оказалось наличие информационной компетентности, самопрезентации, что включает в себя его аватарку, внешний вид, правильное произношение, скорость реакиии. Настоящее время ставит перед психологом-консультантом такие новые требования: требование к самопрезентации - при консультации через скайп психолог должен понимать важность своего внешнего вида, обязан соответствовать тому образу, которого требует профессия, и иметь опрятный вид; при консультачии в чатах, форумах и в соисетях аватарка долэна соответствовать профессиональному содержанию, желательно, чтобы это была фотография самого консультанта, отражающия его профессиональную фигуру. Требование к обладанию информационной компетентностью, когда психолог-консультант понимает, что при недоскональном владении техническими средствами существует возможность прерывания онлайн-консультации, и клиент может никогда не решиться на подобное общение онлайн. Требование к письменной грамотности психолога: при консультации в чатах, форумах и соисетях допущенные психологом ошибки, опечатки могут быть поводом для клиента прекратить консультащию.

Ключевые слова: интернет-консультачия, психологическая помощь, реальное время, информачионная компетентность, самопрезентация, аватар, онлайн-консультация, информационные технологии.

Abstract. Article considers actual questions of psychological help on-line in real time. Revealed promising means of psychological help in distance for people with limitations possibilities, for people who living to far from the cities, and for people who wants maximum to safe anonymous of psychological help. Investigated that psychological help can be providing in various ways, such as: skype, text messager, forums, webinars and others multimedia tools. After processing the results we made some conclusions that the main reguirement to psychologist proved availability of information competence, self-presentation, which include the avatar, appearance, correct pronunciations, guick response. It means that today will confronts for psychological-consultant new reguirements: the reguirements of 
self-presentations, that means that if psychologist have consultations by skype he must undertand the importance of his appearance, it must conform of the image, which reguires proffesion and have to neat appearance, if psychologist have consultations in chats, forums and social networks in his avatar must comply by professional content, it is desirable that it will be photo of consultant, reflecting his professional figure. The reguirement to acguire of information competence is when psychologist-consultant must understand if he has not througly technical it means that in any time online consultation can be interrupted and the client will never more decide to communicate with you online. Reguirement of written literacy of psychologist if he has consultation in chats, forums and social networks, that means that client reads you answer on the screen, in this case if psychologist will make mistake, typos might it will be reason for client to stop consultation.

Keywords: internet psyhelp, psychological help, real time, information competence, self-presentation, avatar, on-line consultation, information technology. 